\title{
Influence of Flexible Working-Time Arrangements on Faculty Satisfaction and Human Resource Retention at Amman Arab University in Jordan
}

\author{
Mohammed Mufaddy Al-Kasasbeh \\ Associate Professor, Faculty of Business, Amman Arab University, Jordan \\ E-mail: mkasasbeh2002@yahoo.com
}

Received: July 28, 2016 Accepted: August 15, 2016 Published: August 19, 2016

doi:10.5296/ijhrs.v6i3.9856 URL: http://dx.doi.org/10.5296/ijhrs.v6i3.9856

\begin{abstract}
This study aims at measuring the influence of flexible working-time arrangements on faculty satisfaction and human resource retention. A questionnaire was developed to collect data from all full-time faculty at Amman Arab University in Jordan which consists of 113 faculty members. 83 valid questionnaires were analyzed which encompass (73.5\%) from all full-time faculty.
\end{abstract}

The most findings of the study are:

- Faculty perceptions about components of flexible working-time arrangements in Amman Arab University are high, except the paragraphs relating to uploading of courses materials on e-learning system from home, and interacting with students on the e-learning system from home, which the relative importance of each is moderate.

- Faculty perceptions about their satisfaction components in Amman Arab University are high, except the paragraphs relating to satisfaction with the system of incentives, compensation, promotion, and the opportunities of participation in decision-making which the relative importance of each is moderate.

- Faculty perceptions about human resource retention components in Amman Arab University are high, except the paragraphs relating to University attention to job security, salaries relative to competitive universities, additional benefits, and career planning which the relative importance of each is moderate.

- There is a statistical influence of flexible working hours on faculty satisfaction and human resource retention. 
- There is no statistical influence of compressed week and telecommuting on faculty satisfaction and human resource retention

Based on the findings of the study, a set of recommendations was proposed to enhance faculty satisfaction and human resource retention in Amman Arab University.

Keywords: Flexible working-time arrangements, Faculty satisfaction, Human resource retention, Amman Arab University

\section{Introduction}

Today's turbulent environment has put pressure on organizations to build agility, improve its adaptability, and implement in a timely manner (AL-Faouri, Al-Nsoor, and AL-Kasasbeh, 2014). Flexible working-time arrangements are one of new trends in human resources management; organizations tend to enhance agility of human resources, and flexibility of operations, in response to various environmental variables. Today's business environment has created several challenges for companies, at the same time there are many opportunities in the environment, organization can capture these opportunities with agility of human resources and flexible working time arrangements. In order to convince the organization management to adopt flexible working time arrangements, the benefits for company must be clear. Therefore, organizations must measure the impact of flexible working-time arrangements to evaluate the positive results of these arrangements.

In recent years, flexible working-time arrangements have received increasingly important interest among researchers and practitioners in the field of human resources management, particularly in the Western countries (Goudswaard, Verbiest, Preenen \& Dhondt, 2013). However, studies in the field of flexible working-time arrangements are still limited in the Arab World (Saleh, \& Hossein, 2010).

Flexible working-time arrangements refer to the arrangements that organizations and employees build to customize the regular working-time patterns in order to meet their changing needs, such as fluctuations in service and production demands or work-life obligations to achieve a balance between business requirements and obligations of the private life of employees (Goudswaard et al., 2013).

There are many benefits of flexible working-time arrangements for organizations and employees in terms of increasing employees productivity, effectiveness of virtual teams, business sustainability, agility of the infrastructure, competitiveness of enterprises, new opportunities, human resource retention, number of female leaders at key positions, ability to attract and retain executives, flexible retirement, and diversified work patterns to achieve the desires of different generations of employees. Other benefits related to reducing the use of work time for personal interest, reduce absences, and shorten the break times during work. The benefits of flexible working-time arrangements vary from one organization to another, but it benefits both employees and organizations.

Jill Evans-Silman believes that organizations which recognize the value of using flexible 
working-time arrangements to bring back time to employees in form of schedules that benefit all employees and organizations will be the successful organizations in new economy (SHRM, 2009).

Human resource recruitment and development processes in most industries and sectors form a significant burden on organizations. Moreover, it is imperative for organizations to attract and retain talented people; because human resource constitutes a crucial resource for success, and human resource retention strategies contribute in achieving sustainable competitive advantages in organizations (Al Nami\& AL-Kasasbeh, 2014).

Amman Arab University (AAU) was chosen to study due to its implementation of flexible working-time arrangements on faculty members in terms of flexible working hours, compressed week, and telecommuting. Something which probably resulted in a supportive environment contributed positive results to the University and faculty members at the same time.

\section{Literature Review \& Study Hypotheses}

According to a survey by the society of human resource management, $59 \%$ of professionals in human resources revealed that their organizations provide flexible working hours for employees, and $37 \%$ of them reported that their organizations adopt a compressed work week. Human resources professionals realized that the difficulty in balancing work-life obligations for employees poses a great threat to retain human resources (SHRM, 2009).

Many studies in the field of human resources management investigated various corporate flexibility strategies (Cappelli \& Neumark, 2003). Several organizations started with introducing flexible working-time arrangements to balance work-life obligations. Organizations that adopt flexible working practices are becoming less in turnover, and more than other organizations in employees' satisfaction and commitment. For example, an analysis showed that turnover rate in organizations which used flexible work options like flexible working hours, compressed week, telecommuting, and early or late access to the work place is $5 \%$ less than other organizations that do not use flexible working-time options (North Coast 99, 2013).

Some previous studies (Kalpana, 2013) found that there are factors affecting employees' job satisfaction, their productivity, and motivations; which lead to reduced levels of job stress. These factors include flexible time schedules that contribute to improving productivity, job satisfaction, and motivation. Moreover, flexible time schedules make organizations more profitable and successful. One study (Russell, O'Connell, \& McGinnity, 2009) concluded that telecommuting is associated significantly with reduced levels of job stress and achieve balance between work and life.

Motives for using flexible working-time arrangements vary. Results of some studies (Shockley \& Allen, 2012) indicated that many employees are motivated to use flexible work-time arrangements by factors related to work rather than motivations related to management of their life. 
Today's business started to go away from focusing on the standard time practices and control how employees spend their time at work within organizations to focus on results and application of flexible working-time initiatives, which may lead to reduced levels of turnover and consequently affects organizational innovation (Moen, Kelly \& Hill, 2011)

Many researchers (Armstrong, Cynthia, Riemenschneider, Allen, and Margaret, 2007; Kelly \& Moen, 2007; Hill, Nicole, Lukas, Dawn, Robyn, Alexis, \& Maria, 2006) believe that giving more flexibility to employees may improve company ability to retain them.

A survey (American Time Use Survey, 2011; cited in The Council of Economic Advisers, 2014) indicated that employees with higher educational levels often adopt flexible working time-arrangements, both concerning the use of flexible working hours or flexible work places.

Some studies (McNall, Masuda, \&Nicklin, 2010) suggest from an empirical point of view that organizations adopt specific policies such as flexible time and compressed work weeks facilitate work and family enrichment, enhance job satisfaction levels, and retain employees. More levels of flexibility granted by companies to employees will able them to achieve some kind of balance between work and personal life. 90000 employees in a survey conducted at 18 countries have determined balance between work and life as the most important factor that they take it into account when choosing a job, and the ability to balance work -life is their motive to stay at work. Organizations that are considering recruiting and retaining talented people have to take in consideration the theme of balance between work and life.

Flexible work options are viewed as an engine of economic growth in governments that are looking for a change in working practices. For example, more than two thirds of managers in United Kingdom believe that it must assist organizations in applying flexible working hours to stimulate economic growth. (Regus, 2012). $72 \%$ of managers and global business owners who responded to a survey acknowledged that improving productivity was a direct result of flexible working practices; for instance in emerging economies $90 \%$ of Chinese managers, $84 \%$ of Mexican managers, and $79 \%$ of Indian managers indicated to the benefits of flexible work for productivity. While in western economies $71 \%$ of American managers, $69 \%$ of French managers, and $68 \%$ of British managers realized that flexibility is an engine of productivity. At the same time $51 \%$ of Japanese managers indicated that there is a relationship between flexible work and productivity.

Study of Chung \& Tijdens (2013) classified twenty one European country according to its use of flexible working-time arrangements in three groups: The first group is South Europe with Hungary and Slovenia where employees and organizations do not use flexible working-time arrangements. The second group consists of Northern Europe with Greece and Poland; where employees and organizations are intensively using flexible working-time arrangements. The third group consists of the rest of the European countries, where the rate of using flexible working-time arrangements is in the middle between Northern Europe and Southern Europe

Saleh \&Hussein's study (2010) found that faculty members in Mosul University have a high flexibility to choose their schedules, times of entry, and exit to the University. This may be a 


\section{Macrothink}

International Journal of Human Resource Studies

ISSN 2162-3058 2016, Vol. 6, No. 3

practice of the idea of flexible work. The study also showed that there is a desire of administrative employees to benefit from flexible working hours as faculty members due to their belief that it will bring them many benefits.

It is expected that present study will be important by adding new information to leaders and academics at AAU in Jordan which contribute to assess the practices of flexible working-time arrangements and its impact on faculty satisfaction and human resource retention. New knowledge might contribute to the related previous literature by bridging the gap in terms of the influence of flexible working-time arrangements on faculty satisfaction and human resource retention.

After reviewing the relevant literature, two main hypotheses were proposed:

H 1: Flexible working-time arrangements (compressed week, flexible working hours, and telecommuting) are positively related to the faculty satisfaction. The following three sub-hypotheses were derived from the first main hypothesis:

$\mathrm{H}$ 1-1: Compressed week is positively related to the faculty satisfaction.

$\mathrm{H}_{1-2}$ : Flexible working hours are positively related to the faculty satisfaction.

$\mathrm{H}_{1-3}$ : Telecommuting is positively related to the faculty satisfaction.

$\mathrm{H}_{2}$ : Flexible working-time arrangements (compressed week, flexible working hours, and telecommuting) are positively related to the human resource retention. The following three sub-hypotheses were derived from the second main hypothesis:

$\mathrm{H}_{2-1}$ : Compressed week is positively related to the human resource retention.

$\mathrm{H}_{2-2}$ : Flexible working hours are positively related to the human resource retention.

$\mathrm{H}_{2-3}$ : Telecommuting is positively related to the human resource retention.

Figure 1demonstratestheoretical framework of the present study, which comprises of flexible working-time arrangements (compressed week, flexible working hours, and telecommuting) as independent constructs and faculty satisfaction and human resource retention as dependent constructs. 


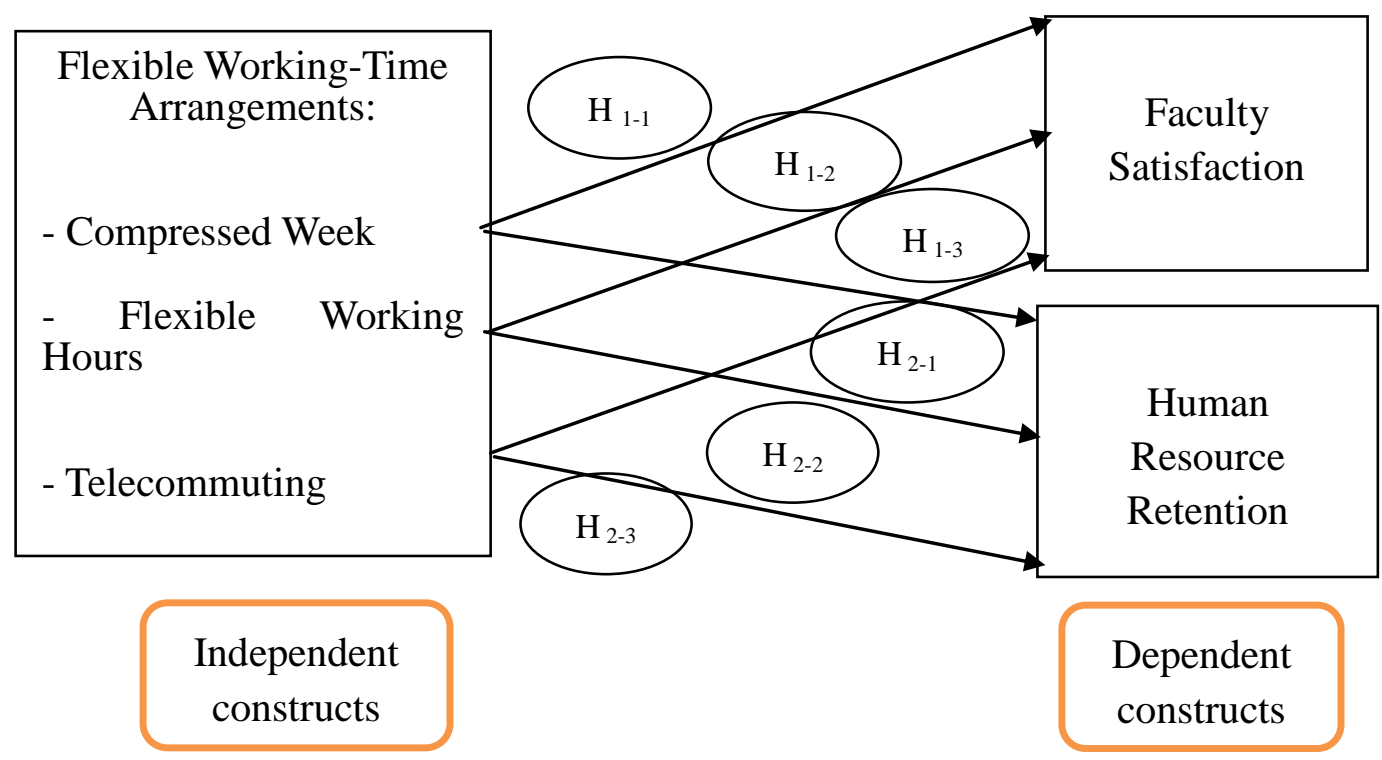

Figure 1 Theoretical Framework

To make constructs more operationalized and measurable in a realistic way, it is important to view the behavioral dimensions, or components denoted by the concept (Zikmund, Babin, Carr, \& Griffin,, 2013; Sekaran \& Bougie, 2013) and subdividing constructs into several measurable items to measure flexible working-time arrangements, faculty satisfaction, and human resource retention respectively.

\section{Research Methodology}

This research is a quantitative study. A questionnaire was distributed to all full-time faculty in AAU to collect data about investigated variables and test the study hypotheses.

\subsection{Amman Arab University}

AAU was founded in 1999 to be a distinctive university such as the prestigious universities in the developed world. AAU is working to achieve excellence in two goals. First, to transfer the university message honestly and to perform its roles efficiently and effectively so as to achieve its goals. The second goal, to be a model university emulated in the Arab world. The main reason behind the establishment of AAU was to basically be an outstanding none-for-profit university (AAU Website, 2016).

\subsection{Unit of Analysis}

The unit of analysis involves all full-time faculty at AAU; because they are involved in AAU's practices of flexible working-time arrangements (compressed week, flexible working hours, and telecommuting)that are related to satisfaction and human resource relation. 113 questionnaires were distributed to all full-time faculty at AAU, 83 valid questionnaires were analyzed which encompass $(73.5 \%)$ from all full-time faculty. 


\subsection{Research Tool}

After reviewing previous studies (Kelly and Kalev, 2006; McNall, Masuda, \& Nicklin, 2010; Shockley \& Allen, 2012; Kalpana, 2013), questionnaire was developed to measure flexible working-time arrangements (compressed week, flexible working hours, and telecommuting), faculty satisfaction and human resource relation constructs. The questionnaire comprised of (40) items according to quintet Likert scale.

\subsection{Validity of Research Tool}

Questionnaire of the study was reviewed by professionals in the field of human resource management to ensure that the items of the questionnaire can measure flexible working-time arrangements (compressed week, flexible working hours, and telecommuting), faculty satisfaction and human resource relation constructs.

\subsection{Reliability of Research Tool}

To verify the internal consistency of study variables, analysis of Cronbach alpha coefficient was used. Table 1displays reliability coefficients of flexible working-time arrangements, faculty satisfaction, and human resource retention constructs that exceeded $70 \%$.

Table 1: Cronbach Alpha Coefficients

\begin{tabular}{ll}
\hline Variables & Cronbach Alpha \\
\hline Compressed Week & $\mathbf{0 . 9 2 9}$ \\
Flexible Working Hours & $\mathbf{0 . 7 0 6}$ \\
Telecommuting & $\mathbf{0 8 4 5}$ \\
Faculty Satisfaction & $\mathbf{0 . 8 9 5}$ \\
Human Resource Retention & $\mathbf{0 . 9 4 0}$ \\
\hline
\end{tabular}

\section{Research Findings}

\subsection{Faculty Perceptions about Research Constructs}

To measure faculty perceptions about the research constructs, an importance level of the answers of the questionnaire items was calculated by the following equation:

Class Length $=$ (maximum response-minimum response $) /$ number of importance levels.

Class Length $=(5-1) / 3=1.33$ 


\section{Macrothink}

International Journal of Human Resource Studies

ISSN 2162-3058

The mean of low importance level is ranging from 1-2.33, the mean of moderate importance level is ranging from 2.34-3.66, and the mean of high importance level is ranging from 3.67-5.

\subsubsection{Perceptions of Faculty about Flexible Working-Time Arrangements}

Table 2 shows that the perceptions of faculty about all items of the flexible working-time arrangements are high with the exception of items 13 and 14 are moderate with means (3.6145) and (3.3855), respectively.

Table 2. Mean, Standard Deviations, and Significance Level for Items of Flexible Working-Time Arrangements.

\begin{tabular}{|c|c|c|c|c|}
\hline NO. & Item & Mean & S.D. & Sig. Level \\
\hline 1 & $\begin{array}{l}\text { AAU affords me the opportunity to work } \\
\text { four days a week. }\end{array}$ & 4.5181 & .75485 & High \\
\hline 2 & $\begin{array}{l}\text { Work four days a week helps me to } \\
\text { manage my time. }\end{array}$ & 4.5060 & .75504 & High \\
\hline 3 & $\begin{array}{l}\text { Work four days a week enables me to meet } \\
\text { my family obligations. }\end{array}$ & 4.4940 & .81710 & High \\
\hline 4 & $\begin{array}{l}\text { Work four days a week enables me to meet } \\
\text { my social obligations. }\end{array}$ & 4.3855 & .90838 & High \\
\hline 5 & $\begin{array}{l}\text { I participate in choosing schedule of my } \\
\text { lectures at AAU. }\end{array}$ & 3.8313 & 1.05714 & High \\
\hline 6 & $\begin{array}{l}\text { AAU is enabling me to choose my office } \\
\text { hours schedule }\end{array}$ & 4.3614 & .65478 & High \\
\hline 7 & $\begin{array}{l}\text { I participate in choosing schedule of my } \\
\text { committees meetings. }\end{array}$ & 3.7108 & .87694 & High \\
\hline 8 & $\begin{array}{l}\text { My work does not exceed } 30 \text { hours a week } \\
\text { at AAU. }\end{array}$ & 3.8795 & .91595 & High \\
\hline 9 & I prepare for lectures in my home. & 4.3735 & .77634 & High \\
\hline 10 & $\begin{array}{l}\text { I mark students' answers sheets in my } \\
\text { home. }\end{array}$ & 4.3012 & .82247 & High \\
\hline 11 & I write scientific researches in my home. & 4.2892 & .89074 & High \\
\hline 12 & $\begin{array}{l}\text { I review students' assignments in my } \\
\text { home. }\end{array}$ & 4.0120 & .91723 & High \\
\hline 13 & $\begin{array}{l}\text { I upload courses material on e-learning } \\
\text { system from my home. }\end{array}$ & 3.6145 & .96058 & Moderate \\
\hline 14 & $\begin{array}{l}\text { I interact with students on the e-learning } \\
\text { system from my home. }\end{array}$ & 3.3855 & .90838 & Moderate \\
\hline 15 & $\begin{array}{l}\text { I review scientific researches for refereed } \\
\text { journals in my home. }\end{array}$ & 4.0000 & .86954 & High \\
\hline \multirow[t]{2}{*}{16} & I review students' theses in my home. & 4.0241 & .82604 & High \\
\hline & General Mean & 4.1054 & & High \\
\hline
\end{tabular}


4.1.2 Perceptions of Faculty about Faculty Satisfaction

Table 3displays that the perceptions of faculty about all items of their satisfaction are high with the exception of items 19, 20, 21, and 26 are moderate with means (3.3494), (3.4096), (3.2289), and (3.4940) respectively.

Table 3.Mean, Standard Deviations, and Significance Level for Items of Faculty Satisfaction

\begin{tabular}{|c|c|c|c|c|}
\hline $\begin{array}{l}\mathbf{N} \\
\mathbf{O} .\end{array}$ & Item & Mean & S.D. & Sig. Level \\
\hline 17 & $\begin{array}{l}\text { AAU provides me with all facilities to } \\
\text { perform my job. }\end{array}$ & 3.9398 & .97966 & High \\
\hline 18 & $\begin{array}{l}\text { I'm satisfied with my work environment } \\
\text { at AAU. }\end{array}$ & 4.1566 & .86224 & High \\
\hline 19 & $\begin{array}{l}\text { I feel that faculty incentives system is } \\
\text { fair at AAU. }\end{array}$ & 3.3494 & 1.14160 & Moderate \\
\hline 20 & $\begin{array}{l}\text { I feel that my salary is equivalent to the } \\
\text { effort involved in performing tasks. }\end{array}$ & 3.4096 & 1.09362 & Moderate \\
\hline 21 & $\begin{array}{l}\text { I feel that faculty promotion system is } \\
\text { fair at AAU }\end{array}$ & 3.2289 & 1.02797 & Moderate \\
\hline 22 & $\begin{array}{l}\text { I feel that there is a continuous } \\
\text { cooperation with colleagues at AAU. }\end{array}$ & 3.9639 & .86173 & High \\
\hline 23 & $\begin{array}{l}\text { AAU provides a necessary information } \\
\text { to do my job. }\end{array}$ & 3.8795 & .73911 & High \\
\hline 24 & $\begin{array}{l}\text { AAU provides an opportunity for team } \\
\text { work. }\end{array}$ & 3.8675 & .79282 & High \\
\hline 25 & $\begin{array}{l}\text { AAU provides training opportunities to } \\
\text { improve performance of my current job. }\end{array}$ & 3.8313 & .89469 & High \\
\hline 26 & $\begin{array}{l}\text { AAU provides opportunities of } \\
\text { participating in decision making which } \\
\text { related to my job. }\end{array}$ & 3.4940 & .96744 & Moderate \\
\hline 27 & I draw a bright image for AAU. & 4.6867 & .51626 & High \\
\hline 28 & I participate in AAU success. & 4.0000 & .47691 & High \\
\hline 29 & $\begin{array}{l}\text { I dislike any negative criticism directed } \\
\text { to AAU. }\end{array}$ & 4.2771 & 1.01589 & High \\
\hline 30 & $\begin{array}{l}\text { Overall, I like my job at AAU. } \\
\text { General Mean }\end{array}$ & $\begin{array}{c}4.5904 \\
3.9604\end{array}$ & .64461 & $\begin{array}{l}\text { High } \\
\text { High }\end{array}$ \\
\hline
\end{tabular}

\subsubsection{Perceptions of Faculty about Human Resource Retention}

Table 4 shows that the faculty' perceptions about items of human resource retention are high with the exception of items 32, 35, 36, and 38 are moderate with means (3.6145), (3.5060), (3.2530), and (3.6265) respectively. 
Table 4. Mean, Standard Deviations, and Significance Level for Items of Human Resource Retention

\begin{tabular}{|c|c|c|c|c|}
\hline NO. & Item & Mean & S.D & Sig. Level \\
\hline 31 & AAU adopts faculty retention policy. & 3.8313 & .90822 & High \\
\hline 32 & $\begin{array}{l}\text { AAU provides job security for faculty } \\
\text { members }\end{array}$ & 3.6145 & .89485 & Moderate \\
\hline 33 & $\begin{array}{l}\text { My job at AAU affords me social status } \\
\text { commensurate with my ambitions. }\end{array}$ & 4.0241 & .78049 & High \\
\hline 34 & My job at AAU affords me self-actualization & 4.0843 & .78406 & High \\
\hline 35 & $\begin{array}{l}\text { AAU provides higher faculty salaries than the } \\
\text { salaries of their colleagues in other } \\
\text { universities. }\end{array}$ & 3.5060 & 1.07492 & Moderate \\
\hline 36 & $\begin{array}{l}\text { AAU offers additional benefits to retain } \\
\text { faculty members. }\end{array}$ & 3.2530 & 1.14597 & Moderate \\
\hline 37 & AAU helps me to cope with my colleagues & 3.8193 & .89911 & High \\
\hline 38 & AAU contributes in career planning for & 3.6265 & .94625 & Moderate \\
\hline 39 & Imemhers & 3.7831 & .85609 & High \\
\hline \multirow[t]{2}{*}{40} & $\begin{array}{l}\text { AAU contributes in developing my skills to } \\
\text { perform future jobs. }\end{array}$ & 4.2771 & .83100 & High \\
\hline & I don't think about leaving my job at AAU & 3.78192 & & High \\
\hline
\end{tabular}

\subsection{Hypotheses Testing}

Table 5 indicates based in the results of multiple regression analysis that there is no statistical influence of compressed week on faculty satisfaction; Beta $=.076, \mathrm{P}=.392$ therefore, hypothesis H1-1 is rejected. And there is no statistical influence of telecommuting on faculty satisfaction; Beta $=.071, \mathrm{P}=.394$ as a result, $\mathrm{H} 1-3$ is rejected. But multiple regression analysis indicates that there is a statistical influence of flexible working hours on faculty satisfaction; Beta $=.642, \mathrm{P}=0.000$ thus, hypothesis $\mathrm{H} 1-2$ is supported. 


\section{Macrothink}

International Journal of Human Resource Studies

ISSN 2162-3058

Table 5.MultipleRegression Analysis forInfluence of Flexible Working-Time Arrangements on Faculty Satisfaction

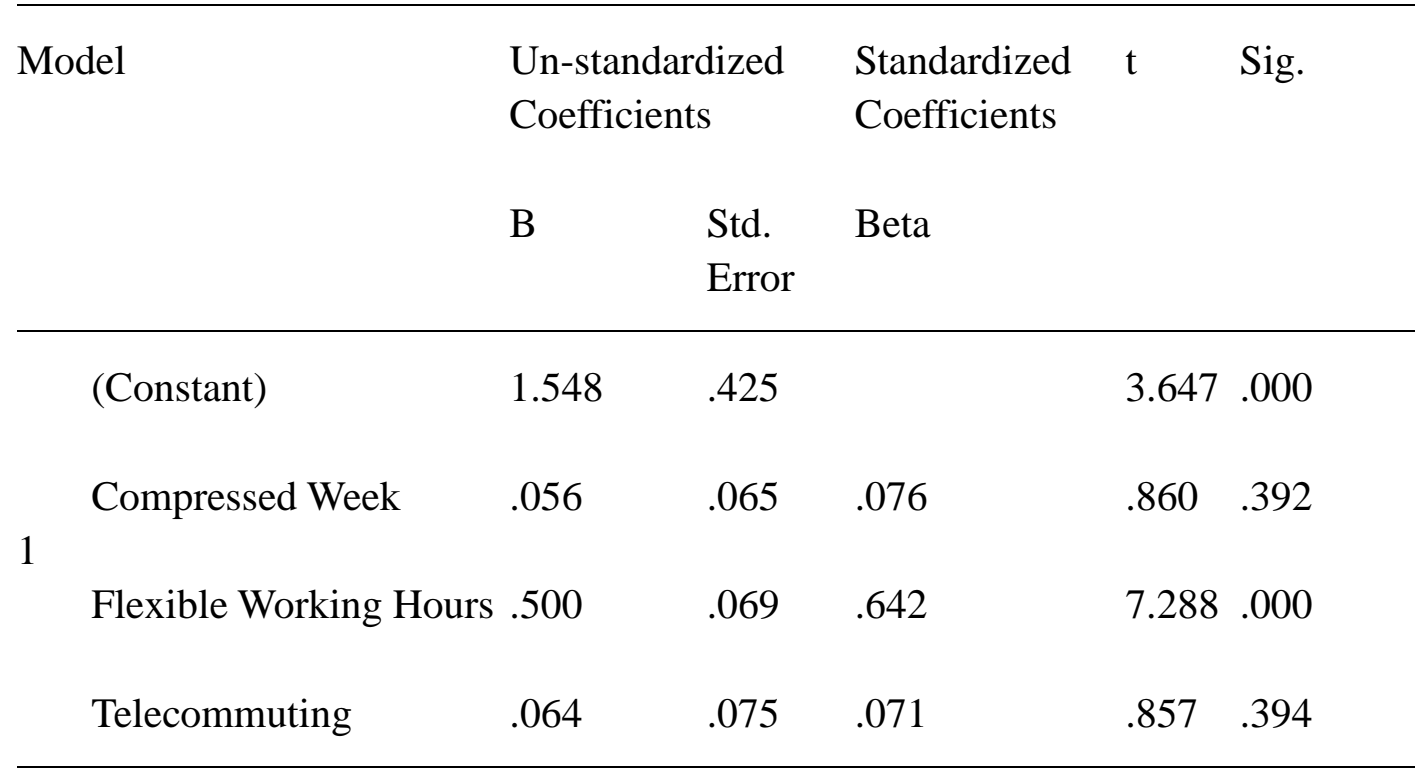

Dependent Construct: Faculty Satisfaction

Table 6 indicates that there is no statistical influence of compressed week on human resource retention in AAU; Beta $=.039, \mathrm{P}=.706$ as a result, hypothesis $\mathrm{H} 2-1$ is rejected. Also there is no statistical influence of telecommuting on human resource retention; Beta $=-.085, \mathrm{P}$ $=.380$. Thus, hypothesis H2-3 is rejected. Whereas, there is a statistical influence of flexible working hours on human resource retention; Beta $=.497, \mathrm{P}=0.000$ Therefore, hypothesis $\mathrm{H} 2-2$ is supported.

Table 6.Multiple Regression Analysis for Influence of Flexible Working-Time Arrangements on Human Resource Retention

\begin{tabular}{|c|c|c|c|c|c|c|}
\hline \multicolumn{2}{|c|}{ Model } & \multicolumn{2}{|c|}{$\begin{array}{l}\text { Un-standardized } \\
\text { Coefficients }\end{array}$} & \multirow{2}{*}{$\begin{array}{l}\text { Standardized } \\
\text { Coefficients } \\
\text { Beta }\end{array}$} & \multirow[t]{2}{*}{$\mathrm{t}$} & \multirow[t]{2}{*}{ Sig. } \\
\hline & & B & Std. 1 & & & \\
\hline \multirow{4}{*}{1} & (Constant) & 1.422 & .616 & & 2.308 & .024 \\
\hline & Compressed Wee & .036 & .095 & .039 & .379 & .706 \\
\hline & $\begin{array}{l}\text { Flexible } \\
\text { Hours }\end{array}$ & $\operatorname{ng}_{.485}$ & .100 & .497 & 4.868 & .000 \\
\hline & Telecommuting & .096 & .109 & .085 & .882 & .380 \\
\hline
\end{tabular}

Dependent Construct: Human Resource Retention 


\section{Conclusion}

The aim of present study is to measure the influence of flexible working-time arrangements on faculty satisfaction and human resource retention in AAU. The conclusions of the study are:

-The perceptions of faculty about all items of the flexible working-time arrangements were high except the paragraphs relating to uploading of courses materials on e-learning system from home, and interacting with students on the e-learning system from home, which the relative importance of each was moderate.

This may be because AAU was late in applying e-learning system to the second semester of the academic year 2004/2005, therefore, some faculty skills are still limited in the use of e-learning system and interact with students on the discussion board from home.

-The perceptions of faculty about the items of faculty satisfaction were high except the paragraphs relating to satisfaction with the system of incentives, compensation, promotion, and the opportunities of participation in decision-making which the relative importance of each was moderate.

The reason might be because AAU did not develop an attractive incentive and compensation systems due to the difficult financial conditions of the past three years, resulting from the low numbers of AAU students for several reasons including transition to permanent site, government policies in reducing the number of high school graduates, admission students policies of Higher Education Ministry that give public universities number of students more than its capacity, and AAU high standards of promotion criteria which are more difficult than other Jordanian public and private universities, which reflected on the satisfaction of faculty members on the promotion system. AAU also initiated several fast plans for development, some faculty members may be felt that decisions taken centrally and they do not have the opportunity of making important decisions in university.

- The perceptions of faculty about items of human resource retention were high except the paragraphs relating to university attention to job security, salaries relative to competitive universities, additional benefits, and career planning which the relative importance of each was moderate.

The reason for this might be because AAU is trying to retain only distinguished university faculty, and searching to attract distinct competencies rather than faculty members with low performance that do not comply with the measurements of the university in the entrepreneurship and excellence. Moreover, a lack of university funding to establish a competitive compensation and benefits systems, Furthermore, university may be believe such as other organizations that career planning is a responsibility of the faculty member himself.

-There is no statistical influence of compressed week and telecommuting on faculty satisfaction and human resource retention.

-There is a statistical influence of flexible working hours on faculty satisfaction and human resource retention. This result is consistent with the study of Kalpana (2013) that flexible 
time schedules contribute in improving job satisfaction. This result is also consistent with the findings of a number of researchers (Armstrong et al, 2007; Kelly \& Moen, 2007; Hill et al., 2006) that giving more flexibility to employees improves ability of firm in retention management.

\section{Implications}

The research implications are;

1-Since there is a positive influence of flexible working hours on both of faculty satisfaction and human resource retention, it is necessary to pay more attention to develop faculty skills and attitudes in the use of e-learning system and interact with students from home.

2- AAU is advised to pay more attention to develop supportive incentives, compensation, career planning and additional benefits systems in line with the university's vision of entrepreneurship and excellence to enable the university to attract faculty and retain them.

3- Modify faculty promotion system in accordance with the University of Jordan faculty regulations as approved to be applied in AAU according to Jordanian Universities Act through reducing terms that make the promotion system in AAU more difficult than University of Jordan and other public and private Jordanian universities. This might make faculty member feel in fairness when comparing faculty promotion criteria in AAU with other national universities.

4- Continue to apply flexible working-time arrangements on faculty members due to the positive effects on satisfaction and retention of faculty members at the university.

\section{Limitations}

Since the data was gathered from one university, generalizability to other universities and firms might be restricted. Therefore, further studies is recommended to be conducted on the constructs of flexible working-time arrangements, job satisfaction, and human resource retention at other universities and companies in Jordan.

\section{Acknowledgments}

The researcher is grateful to Scientific Research Deanship at AAU in Jordan for sponsoring this research.

\section{References}

AL-Faouri, A., Al-Nsoor, M., and AL-Kasasbeh, M. (2014). "The Impact of Workforce Agility on Organizational Memory". Knowledge Management Research \& Practice. 12(4), 432-442.doi:10.1057/kmrp.2013.19

Al Nami, S. \& AL-Kasasbeh, M. (2014). Human Resource Retention Strategies and its Role in enhancing Performance of Procurement and Warehouse Department at Abu Dhabi Police 
GHQ. Journal of AL-Quds Open University for Administrative \& Economic Research \& Studies. 1(1), 55-87.

Akuoko, K. O., and Ansong, F. (2012). Employee Retention Strategies and Workers' Performance: General Views of Employees in Ashanti Region of Ghana.International Journal of Business and Management Tomorrow. 2 (8), 1-9.

Armstrong, Deborah, Cynthia K. Riemenschneider, Myria W. Allen, and Margaret F. Reid. (2007). Advancement, Voluntary Turnover, and Women in IT: A Cognitive Study of Work-Family Conflict. Information \& Management, 44:142-53.

Cappelli, P., and Neumark, D. (2003), External Churning and Internal Flexibility: Evidence on theFunctional Flexibility and Core-Periphery Hypotheses, Industrial Relations, 43, 1, $148-182$.

Chung, H. \&Tijdens, K. (2013). Working Time Flexibility Components and Working Time Regimes in Europe: Using Company-Level Data across 21 Countries. The International Journal of Human Resource Management. 24(7), 1418-1434.

Eldridge, D. \&Nisar T. M., (2011). Employee and Organizational Impacts of Flexitime Work Arrangements. Industrial Relations -66(2), 213-234.

Goudswaard, A. Verbiest S., Preenen, P. \&Dhondt, S. (2013). Creating Successful Flexible Working-Time Arrangements: Three European Case Studies. Employment Relations Today. Published Online in Wiley Online Library (wileyonlinelibrary.com). DOI 10.1002/ert.21418.

Hill, E. Jeffrey, Nicole, T. Mead, Lukas R. Dean, Dawn M. Hafen, Robyn Gadd, Alexis A.Palmer, \& Maria S. Ferris. (2006). Researching the 60-Hour Dual-Earner Workweek: An Alternative to the 'Opt-Out Revolution. American Behavioral Scientist. 49:1184-1203.

Kalpana R. S. (2013). Flextime Association with Job Satisfaction, Work Productivity, Motivation \& Employees Stress Levels. Journal of Human Resource Management. 1 (1), 9-14. doi: 10.11648/j.jhrm.20130101.12

Kelly E. L. \&Kalev A. (2006). Managing Flexible Work Arrangements in US Organizations: Formalized Discretion or 'A Right to Ask'. Socio-Economic Review. 4, 379-416

Kelly, E. L. \& Moen, P. (2007). "Rethinking the Clockwork of Work: Why Schedule Control May Pay Off at Home and at Work. Advances in Developing Human Resources. 9:487-506.

McNall, L. A., Masuda, A. D., \&Nicklin J. M. (2010). Flexible Work Arrangements, Job Satisfaction, and Turnover Intentions: The Mediating Role of Work-to-Family Enrichment. The Journal of Psychology, 144(1), 61-81.

Moen, P. Kelly, E. L., \&Hill, R. (2011). Does Enhancing Work-Time Control and Flexibility Reduce Turnover? A Naturally Occurring Experiment. Social Problems. 58 (1), 69-98.

NorthCoast 99. (2013). Flexible Work: Trends \& Best Practices. www.northcoast99.org. 


\section{Macrothink}

International Journal of Human Resource Studies

ISSN 2162-3058 2016, Vol. 6, No. 3

Regus, (2012). Flexibility Drives Productivity. [Online], [Retrieved December 3, 2015]. Available at: http://www.regus.com/images/Flexibility\%20Drives\%20 Productivity_ tcm8-49367.pdf

Russell, H.O'Connell, P. J. \&McGinnity, F.(2009). The Impact of Flexible Working Arrangements on Work-life Conflict and Work Pressure in Ireland. Gender, Work and Organization. 16 (1), 73-97.

Saleh, S. G. \&Hussein,E.T. (2010).The Employees Wishes to Benefit from FlexibleWorking Hours: A Study in Musel University. Tikrit Journal for Economic \& Administrative Sciences. 6(17), 9-30.s

Sekaran, U., and Bougie, R. (2013). Research Methods for Business: A Skill-Building Approach. 6th edition. John Wiley and Sons Inc.

Shockley, K.M. \& Allen, T.D. (2012). Motives for Flexible Work Arrangement Use. Community, Work \& Family. 15(2), 217-231.

SHRM. (2009). Workplace Flexibility in the 21st Century: Meeting the Needs of the Changing Workforce. [Online], [Retrieved December 3, 2015]. Available at: www.shrm.org/surveys.

The Council of Economic Advisers, Executive Office of the President of the United States. (2014). Work-Life Balance and the Economics of Workplace Flexibility. [Online], [Retrieved December 3, 2015]. Available at: https://www.whitehouse.gov/sites/default/files/docs/updated_workplace_flex_report_final_0. pdf

Zikmund, W. G., Babin, B. J., Carr, J. C., \& Griffin, M. (2013). Business Research Methods, 9th ed. Australia South-Western.

\section{Copyright Disclaimer}

Copyright for this article is retained by the author(s), with first publication rights granted to the journal.

This is an open-access article distributed under the terms and conditions of the Creative Commons Attribution license (http://creativecommons.org/licenses/by/3.0/). 